\title{
RESSENYES
}

\section{Cultures of the Erotic in Spain, 1898-1936}

Maite Zubiaurre

Nashville, Vanderbilt University Press, 2012

A finales del XIX, España se sumió en una crisis cultural a raíz de la pérdida de las colonias en 1898 cuyo dolor cristalizó en una constelación de grandes obras literarias que han llevado a considerar el período como la Edad de Plata. Ese es el relato acerca del período que ha dominado la historiografía de la literatura española durante todo el siglo $\mathrm{xx}$ y que sigue en vigencia - pese a las revisiones - en la actualidad. Maite Zubiaurre propone en este volumen un contra-relato, o cuanto menos un relato alternativo a esta narrativa, centrándose en la "otra" producción literaria y cultural del período: la cultura popular, comercial, masiva, cuya presencia fantasmal (en palabras de Jo Labanyi) se contrapone a la alta cultura hipervisibilizada por el canon. Y es que si el tránsito entre siglos supuso todo eso que la historiografía tradicional nos ha contado, también se caracterizó por la eclosión de un mercado editorial masivo que se concretó en infinitas colecciones de novela y prensa literaria, el auge de los espectáculos teatrales de carácter comercial, la explosión del mercado de la imagen a través de postales y fotografías... fenómenos que definieron el período de un modo absolutamente peculiar y que constituyeron una auténtica vanguardia de modernidad.

Cultures of the Erotic in Spain se lanza a explorar estos territorios siguiendo lo que fue el auténtico hilo de continuidad entre ellos: el erotismo y el constante asedio y reformulación de los ideales de género y sexualidad que se negoció en este amplísimo mercado cultural. La autora, pues, acomete una doble tarea: por un lado, el rescate de una abrumadora cantidad de materiales literarios, periodísticos, fotográficos que, además, comparte generosamente en la página web A virtual Wunderkammer (http://sicalipsis.humnet.ucla.edu/), que sirve de apoyo al libro. Por otra parte elabora un brillante y complejo análisis, un completo estudio cultural, en el que se trazan las relaciones entre discursos médicos, literarios, artísticos, pedagógicos, etc. y en el que se evidencian las 
trascendentes cuestiones de política sexual que se debatieron en estos materiales tantas veces tachados de frívolos pero que generaron enorme malestar en la época, especialmente entre la intelectualidad, que alineada con la medicina, la ley o la moralidad no dejó de expresar sus temores ante las sexualidades no normativas que la sicalipsis propagaba.

Así, en los tres primeros capítulos, el volumen enfoca sobre todo en los territorios de la "ley" deteniéndose en aspectos como la proliferación de manuales de sexología cuyo carácter científico y pedagógico fue, en muchas ocasiones, deconstruido a través de consumos mucho más carnales. También se aborda el ambiguo papel del psicoanálisis al sacar los dominios de lo sexual a la opinión pública y patologizar las sexualidades no heteronormativas, lo que resultó un gesto represor que a la postre contribuyó a la popularización y después legitimación de estas alternativas sexuales. E inevitablemente, se analizan las aportaciones de los máximos intelectuales del momento (Ramón y Cajal, Ortega y Gasset, Marañón) a los debates acerca de la sexualidad, sobre todo en su dimensión colectiva y nacional. Con una lectura muy fina, la autora apunta aquí cómo muchos de los intelectuales que invocaban la salud y la norma ante la indiferenciación sexual, androginia y perversidad que parecían degenerar la patria, estaban menos preocupados por la sexualidad en sí misma que por el vigor de la cultura popular en la que esta panoplia de sexualidades alternativas estaba circulando sin parar.

Los dos siguientes capítulos se dedican a explorar dos ámbitos de difusión de la imagen particularmente relevantes: las postales eróticas y las revistas naturistas, que introducen en el imaginario el cuerpo como objeto de deseo y en el caso de las segundas, el cuerpo masculino desnudo, deseante y muy conectado al homoerotismo, que no se había infiltrado en la imaginería erótica corriente (que interesadamente prefería el cuerpo femenino). Ya en el estudio sobre las revistas naturistas, la autora acomete la tónica general de los siguientes capítulos, esto es, el análisis de imágenes concretas que son recurrentes en la prensa sicalíptica y los materiales gráficos eróticos: de las escenas de baño pasamos al clásico motivo de la mujer ante el espejo que también en estos nuevos soportes evoca el narcisismo y la homosexualidad femenina; seguimos con la sugerente imagen de escena de lectura, que conecta la irracionalidad y la pasionalidad de la mujer con su descalificación como lectora pero que, como señala Zubiaurre, no deja de tener un potencial tremendamente contestatario al apuntar al derecho de la mujer a aprender. Las ciclistas y las mecanógrafas, encarnaciones de la ansiedad masculina ante una modernidad y unas tecnologías que son capaces de producir nuevas feminidades, conviven con las majas, las gitanas y las toreras, que saturan la prensa y las variedades sicalípticas reapropiándose de un folklorismo que, en los cuerpos de las cupletistas y sobre todo, en el de sus imitadores travestidos, apunta al territorio de la alteridad y el deseo. Finalmente, el último capítulo se centra en el fenómeno editorial de la novela corta, verdadero 
laboratorio de sexualidades alternativas, en el que aparecieron algunos de los primeros hitos de la literatura homoerótica como El ángel de Sodoma (Hernández Catá, 1927) o Las locas de postín (Retana, 1919).

Maite Zubiaurre transita por estas sendas desgranando un análisis tan agudo como efervescente, que sabe hacer brillar la viveza y el aire festivo de muchos de los textos que trata pero sobre todo, su enorme carga política, en la que se entrelazan cuestiones de género y sexualidad, pero también de clase y nación y en los que se construye y se negocia la noción misma de modernidad. Así las cosas, no cabe más que adherirse a la reflexión que cierra el volumen, reivindicando el interés académico de estos materiales sicalípticos, cuyo estudio, a día de hoy aún sigue viéndose como algo disperso, excéntrico y a veces un tanto amateur, a pesar de la irreverencia, transgresión y vertiente política de estos materiales, que demuestran, sin duda, que lo sexual también es político.

ISABEL ClÚA

D.O.I.:

Universitat de Barcelona 